\title{
Tannic extract potential as natural wood preservative of Acacia mearnsii
}

\author{
AMANDA G. DA SILVEIRA ${ }^{1}$, ELIO J. SANTINI ${ }^{2}$, STELA M. KULCZYNSKI ${ }^{3}$, \\ RÔMULO TREVISAN ${ }^{4}$, ARCI D. WASTOWSKI ${ }^{5}$ and DARCI A. GATTO ${ }^{6}$
${ }^{1}$ Universidade Federal de Santa Maria, Centro de Ciências Rurais, Avenida Roraima, 1000, 97105-900 Santa Maria, RS, Brazil ${ }^{2}$ Universidade Federal de Santa Maria, Departamento de Ciências Florestais, Avenida Roraima, 1000, 97105-900 Santa Maria, RS, Brazil
${ }^{3}$ Universidade Federal de Santa Maria, Departamento de Ciências Agronômicas e Ambientais, Linha 7 de Setembro, s/n, BR 386, Km 40, 98400-000 Frederico Westphalen, RS, Brazil
${ }^{4}$ Universidade Federal de Santa Maria, Departamento de Engenharia Florestal, Linha 7 de Setembro, s/n, BR 386, Km 40, 98400-000 Frederico Westphalen, RS, Brazil
${ }^{5}$ Universidade Federal de Santa Maria, Departamento de Engenharia e Tecnologia Ambiental, Linha 7 de Setembro, s/n, BR 386, Km 40, 98400-000 Frederico Westphalen, RS, Brazil
${ }^{6}$ Universidade Federal de Pelotas, Centro de Engenharias, Rua Conde de Porto Alegre, 793, 96010-290 Pelotas, RS, Brazil

Manuscript received on June 25, 2017; accepted for publication on July 31, 2017

\begin{abstract}
High toxicity of the preservatives most frequently used in wood treatment and the resulting risks of handling pose a threat to small producers and to the environment. In an attempt to mitigate these problems, the present study was conducted with the objective of evaluating the preservative effect of tannic extract on biodeterioration of Acacia mearnsii wood. For this purpose, untreated and preserved specimens, some with tannin extract and some with a preservative mixture based on CCB (Chromated Copper Borate), were submitted to accelerated rotting trials with the fungus that causes white rot (Pycnoporus sanguineus) for 16 weeks. The evaluations were made with a basis on weight loss and chemical components analysis, and they showed that the natural resistance of Acacia wood is moderate when exposed to the white rot fungus. The tannin concentrations showed similar effects to those of the CBB mixture in all evaluations, i.e., they significantly increased the biological resistance of the material, which started to be classified as very resistant to the fungus. Overall, the results suggest that tannin can be considered as a potential natural preservative product.
\end{abstract}

Key words: extractives, laboratory testing, wood quality, white rot.

\section{INTRODUCTION}

Wood is a material broadly used in several industries. It is produced in a natural, renewable manner; because of its unique properties, it can be used both

Correspondence to: Amanda Grassmann da Silveira

E-mail: amandagrassmann@gmail.com in indoor and outdoor environments (GonzálezLaredo et al. 2015). However, the increasing demand for this raw material led to increased use of fast-growing species, which may have shorter lifetime when exposed to environments that allow the development and attack of xylophagous organisms (Temiz et al. 2007, Mohan et al. 2008, 
Ashaduzzaman et al. 2011, Gerengi et al. 2014). Acacia mearnsii, for example, is the only one species of the genus Acacia grown commercially on a significant worldwide scale. It is planted mainly in South Africa and southern Brazil for tannin production and timber exports (Chan et al. 2015).

Natural durability of some species is mainly associated to the accumulation of extractives in the heartwood, some of which delay the rotting process (Morris and Stirling 2012). They are the non-structural components of wood, and some studies have already reported that certain extracts have antifungal and insecticidal properties, hence further research should be conducted on this topic (Stirling 2010, Tascioglu et al. 2013, GonzálezLaredo et al. 2015).

There are many advantages in using wood extractives as natural preservatives. These products are safer than synthetic preservatives because there are fewer manipulation risks for the operators involved in wood treatment and elimination of toxic residues; thus, they also reduce the impact on the environment (Arango et al. 2005, Islam et al. 2009, Tascioglu et al. 2013).

The use of products that include boron, chromium, arsenic and other heavy metals has declined in many countries in Europe and North America because they are considered to be potential polluters (Gerengi et al. 2014). However, according to the list of the Brazilian Institute of the Environment and Renewable Natural Resources (IBAMA), one of the most common preservatives allowed in wood treatment is CCB (Chromated Copper Borate), an alternative to the traditional CCA (Chromated Copper Arsenate). Advantages include absence of arsenic and lower toxicity to humans and the environment (Vidal et al. 2015).

New formulations for wood protection based on previously developed preservative mixtures (non-metallic or organic) - offer some real advantages, but they are not yet definitive
(Feraydoni and Hosseinihashemi 2012, Tondi et al. 2012). Thus, combining certain metals with organic biocides may increase their efficacy (González-Laredo et al. 2015) and satisfactory results have already been reported (Feraydoni and Hosseinihashemi 2012).

As described in the literature, there is a correlation between changes in chemical composition and resistance properties of treated wood (Winandy 1995, Winandy and Lebow 1996, Karimi et al. 2013). Thus, understanding the relation between the chemical components that compose the material in the different phases of degradation may provide new strategies for the preservation industry while also allowing the choice of a more effective preservative (Gosh et al. 2012).

In a field of research whose purpose is to protect wood with natural substances, tannins are considered to be the ideal solution (Laks et al. 1988); based on this finding, other research groups have decided to follow a similar line of research (Yamaguchi and Okuda 1998, Taylor et al. 2006, Tascioglu et al. 2012, Tondi et al. 2015). Therefore, the objective of this study was to evaluate the preservative effect of tannic extract on biodeterioration of wood of Acacia mearnsii.

\section{MATERIALS AND METHODS}

\section{PREPARATION OF MATERIAL AND SPECIMENS}

The material used as raw material was purchased in homogeneous commercial plantations of Acacia mearnsii from the company SETA, in Estância Velha-RS. Tree selection was based on diameter $(15 \mathrm{~cm})$, straightness and stem health appearance. After the selected population had been mapped, five trees were cut down. Afterwards, the selected trees were cut into logs measuring $2.0 \mathrm{~m}$ in length, and the first and second logs after the tree base were sampled. Subsequently, three discs were cut out from the logs to prepare the specimens, according 
to the standards of the American Society for Testing and Materials - ASTM D-2017 (1994).

Thirty discs were created and 120 specimens were prepared out of a total of $10 \mathrm{logs} ; 20$ were used in the tannin preservative (in the concentrations of 5 and 10\%), 10 for the chromium-copper-boron mix treatment (CCB mix) and 10 for subsequent evaluation of natural resistance of the wood material (no treatment). As for the rest of the specimens, 30 samples were selected for the evaluation of the chemical components of wood (cellulose, hemicellulose and lignin), referred to as control samples (higher control); they were not exposed to the fungus. The remaining 50 specimens were stored for any occasional need of replacement.

Tannin, a natural compound from Acacia mearnsii, was extracted by the company SETA. According to the company's specifications, there was a minimum tanner value of $73 \%$ and maximum moisture of $7 \%$. In general, industrial extraction usually occurs in hot water containing low concentrations of sodium salts that improve the quantity and quality of the tannin extract (Chen 1991).

After the specimens were sanded, selected and acclimatized, they were submitted to treatments T1 (tannin solution at 5\% concentration), T2 (tannin solution at $10 \%$ concentration) and T3 (CCB mixture at $2.5 \%$ ). They individually underwent the full-cell pressure treatment in an autoclave, for an initial vacuum period of 15 minutes and, subsequently, pressure for 60 minutes. In T0 (lower control) and in the control samples, no were preservative treatments were performed because an evaluation was made of natural resistance and properties of the wood that was not exposed to rotting.

\section{LABORATORY TESTING}

The colony with fragments of the white rot fungus, Pycnoporus sanguineus, was supplied by the Wood
Biodegradation and Preservation Department - LPF / IBAMA. Laboratory testing was composed of four treatments (T0, T1, T2 and T3) as recommended by ASTM D-2017 (1994). First, a feeding plate of Pinus sp. was used as substrate for the initial establishment of the fungal colony. Later, according to each treatment, the specimens were put in flasks where they were kept for 16 weeks. Subsequently, the samples were dried and weighted, and weight loss was measured.

For the resistance evaluation (natural and treated) to fungus attack, wood weight loss was compared according to the values shown in Table I.

\section{ANALYSIS OF CHEMICAL COMPONENTS OF WOOD}

The sawdust samples in use were classified according to standard Technical Association of the Pulp and Paper Industry TAPPI 257 (2002a), and standard TAPPI 264 (1996a), in triplicate, determined their humidity. The analysis of total extractives was based on standard TAPPI 204 (1996b); and for lignin determination, the carbohydrates of the sample had to be hydrolyzed by sulfuric acid at 72\% (v/v) TAPPI 222 (1999). Sulfuric acid-soluble lignin was determined by ultraviolet absorption (200-208 nm) of the filtrate resulting from Klason lignin.

Cellulose level was measured by the method proposed by TAPPI 203 (2009). Holocellulose level was calculated according to TAPPI 19 (2002b). Hemicellulose percentage was calculated by subtracting the level of cellulose from the level of holocellulose.

TABLE I

Classes of wood resistance to xylophagous fungi (ASTM, 1994).

\begin{tabular}{ccc}
\hline Resistance Classes & $\begin{array}{c}\text { Weight } \\
\text { Loss (\%) }\end{array}$ & $\begin{array}{c}\text { Residual Weight } \\
(\%)\end{array}$ \\
\hline Very Resistant & $0-10$ & $90-100$ \\
Resistant & $11-24$ & $76-89$ \\
Moderately Resistant & $25-44$ & $56-75$ \\
Non-Resistant & $\geq 45$ & $\leq 55$ \\
\hline
\end{tabular}




\section{STATISTICAL ANALYSIS}

The study used a completely randomized design, with four treatments and 10 replications. In order to compare the treatments with higher and lower controls, the averages were compared by orthogonal contrast with significance level of 5\%.

\section{RESULTS AND DISCUSSION}

\section{WEIGHT LOSS}

Analysis of variance and the subsequent use of orthogonal contrasts showed weight loss differences in the wood of the lower (natural resistance) and the higher (treatment with CCB) controls, compared with the tannin-based treatments (Table II).

The wood of Acacia mearnsii without any type of preservative (lower control) showed weight loss of $28.07 \%$; thus, it has moderate natural resistance to fungal attack by Pycnoporus sanguineus. Regarding the use of tannin as a preservative substance, the concentrations of 5\% and $10 \%$ showed very similar performance, with average weight loss between $5.24 \%$ and $5.97 \%$, respectively. Therefore, the wood can be classified as very resistant according to the criteria of ASTM D-2017 (Table I). In the same resistance class is the wood treated with the CCB mixture (higher control), with weight loss of $2.67 \%$.

Such increases indicate that the wood without preservatives (lower control) lost more than $22.0 \%$

TABLE II

Contrasts of average weight loss.

\begin{tabular}{ccc}
\hline Contrast & Average x Average & Increase \\
\hline Lower control x T1* & $28.07 \times 5.97$ & 22.10 \\
Lower control x T2* & $28.07 \times 5.24$ & 22.83 \\
Lower Control x High & $28.07 \times 2.67$ & 25.40 \\
Control* & $2.67 \times 5.97$ & -3.30 \\
Higher control x T1* & $2.67 \times 5.24$ & -2.57 \\
Higher control x T2* & \\
\hline
\end{tabular}

T1 - Tannin treatment 5\%; T2 - Tannin treatment 10\%; Lower control - Wood without preservative; Higher control - Wood treated with CCB; * Significant by the 5\% T-Test. weight in comparison with the tannin treatment; when compared with the higher control, weight loss was $25.4 \%$, i.e., performance was similar to that of tannin and the CCB mixture. When comparing the different tannin rates with the higher control, it could be seen that even though the treatments are statistically different, they were classified in the same biological resistance class, which is indicative of the preservative capacity of tannin.

The findings support the hypothesis that the tannin extract can be potentially used as a natural alternative wood preservation. This claim is corroborated by studies of Tondi et al. (2015), in which tannin was combined with boric acid in the treatment of pine trees. Weight loss of untreated wood was around $56 \%$ compared with $3 \%$ when wood was treated with natural extracts. The authors also argue that the results were even better when the combination was tested with the presence of additives in order to facilitate product retention.

The high antifungal activity of the tannin extract was also assessed in the study on brauna (Schinopsis brasiliensis) trees by Roux (1992), whose findings were similar to the ones in the present study: the species is highly resistant to decomposing fungi, which is due to high tannin levels present in the wood (approximately 33\% of its composition). Similarly, Walker (2006) also found an association between natural durability of wood and concentration of phenolic extractives, e.g., tannin.

Although Acacia mearnsii is known for tannin production, a greater amount of the extract is found in the bark while a smaller proportion is present in the heartwood. For this reason, interestingly, wood was treated with the extractive itself, which increased resistance from moderate to strong compared with weight loss. 


\section{CHEMICAL COMPOSITION}

Table III shows a comparison of average chemical composition of wood from Acacia mearnsii before and after rotting. The treatments were compared with lower and higher controls; respectively, untreated wood exposed to the fungus and control samples that had not been exposed to the fungus.

The values of the main constituents of wood of Acacia mearnsii presented the following percentages: holocellulose, 73.01\%; lignin, $28.21 \%$; and extractives, $4.38 \%$. When studying

TABLE III

Contrasts of the averages of the chemical constituents.

\begin{tabular}{ccc}
\hline Contrasts & Average x Average & Increase \\
\hline \multicolumn{3}{c}{ Extractive } \\
\hline Lower Control x T1 & $3.96 \times 6.12$ & -2.16 \\
Lower Control x T2 & $3.96 \times 6.54$ & -2.58 \\
Lower Control x T3 & $3.96 \times 4.62$ & -0.66 \\
Lower Control x & $3.96 \times 4.38$ & -0.42 \\
$\quad$ High Control & $4.38 \times 6.12$ & -1.74 \\
Higher Control x T1 & $4.38 \times 6.54$ & -2.16 \\
Higher Control x T2 & $4.38 \times 4.62$ & 0.23 \\
Higher Control x T3 &
\end{tabular}

Lignin

\begin{tabular}{|c|c|c|}
\hline $\begin{array}{c}\text { Lower Control x } \\
\text { T1* }\end{array}$ & $22.86 \times 26.94$ & -4.08 \\
\hline $\begin{array}{c}\text { Lower Control x } \\
\text { T2* }\end{array}$ & $22.86 \times 27.50$ & -4.64 \\
\hline $\begin{array}{c}\text { Lower Control x } \\
\text { T3* }\end{array}$ & $22.86 \times 27.55$ & -4.69 \\
\hline $\begin{array}{c}\text { Lower Control x } \\
\text { High Control }\end{array}$ & $22.86 \times 28.21$ & -5.35 \\
\hline Higher Control x T1 & $28.21 \times 26.94$ & 1.27 \\
\hline Higher Control x T2 & $28.21 \times 27.50$ & 0.71 \\
\hline \multirow[t]{2}{*}{ Higher Control x T3 } & $28.21 \times 27.55$ & 0.66 \\
\hline & Holocellulose & \\
\hline $\begin{array}{c}\text { Lower Control x } \\
\text { T1* }\end{array}$ & $60.11 \times 69.7$ & -9.57 \\
\hline $\begin{array}{c}\text { Lower Control x } \\
\text { T2* }\end{array}$ & $60.11 \times 70.36$ & -10.25 \\
\hline
\end{tabular}

TABLE III (continuation)

\begin{tabular}{ccc}
\hline Contrasts & Average x Average & Increase \\
\hline $\begin{array}{c}\text { Lower Control x } \\
\text { T3* }\end{array}$ & $60.11 \times 73.37$ & -13.26 \\
$\begin{array}{c}\text { Lower Control x } \\
\text { High Control* }\end{array}$ & $60.11 \times 73.01$ & -12.9 \\
$\begin{array}{c}\text { Higher Control x } \\
\text { T1* }\end{array}$ & $73.01 \times 69.7$ & 3.31 \\
$\begin{array}{c}\text { Higher Control x } \\
\text { T2* }\end{array}$ & $73.01 \times 70.36$ & 2.65 \\
$\begin{array}{c}\text { Higher Control x } \\
\text { T3* }\end{array}$ & $73.01 \times 72.37$ & 0.64 \\
\hline $\begin{array}{c}\text { Hemicellulose } \\
\text { T1* }\end{array}$ & $26.84 \times 28.28$ & -1.44 \\
\hline $\begin{array}{c}\text { Lower Control x } \\
\text { Tower Control x }\end{array}$ & $26.84 \times 28.67$ & -1.83 \\
$\begin{array}{c}\text { Lower Control x } \\
\text { T3* }\end{array}$ & $26.84 \times 28.87$ & 2.03 \\
$\begin{array}{c}\text { Lower Control x } \\
\text { High Control* }\end{array}$ & $26.84 \times 29.23$ & 2.39 \\
Higher Control x T1 & $29.23 \times 28.28$ & 0.95 \\
$\begin{array}{c}\text { Higher Control x T2 } \\
\text { Higher Control x T3 }\end{array}$ & $29.23 \times 28.67$ & 0.56 \\
\hline & $29.23 \times 28.87$ & 0.36 \\
\hline
\end{tabular}

Cellulose

\begin{tabular}{|c|c|c|}
\hline $\begin{array}{c}\text { Lower Control } \mathrm{x} \\
\mathrm{T} 1 *\end{array}$ & $33.26 \times 41.41$ & -8.15 \\
\hline $\begin{array}{c}\text { Lower Control x } \\
\text { T2* }\end{array}$ & $33.26 \times 41.68$ & -8.42 \\
\hline $\begin{array}{c}\text { Lower Control } \mathrm{x} \\
\text { T3* }\end{array}$ & $33.26 \times 43.49$ & -10.23 \\
\hline $\begin{array}{l}\text { Lower Control x } \\
\text { High Control* }\end{array}$ & $33.26 \times 43.77$ & -10.51 \\
\hline $\begin{array}{c}\text { Higher Control x } \\
\text { T1* }\end{array}$ & $43.77 \times 41.41$ & 2.36 \\
\hline $\begin{array}{l}\text { Higher Control } \mathrm{x} \\
\mathrm{T} 2 *\end{array}$ & $43.77 \times 41.68$ & 2.09 \\
\hline $\begin{array}{c}\text { Higher Control x } \\
\text { T3* }\end{array}$ & 43.77 x 43.49 & 0.28 \\
\hline
\end{tabular}


the same species, T.E.S. Segura et al. (unpublished data) found the following values, respectively: $72.26 \%, 23.48 \%$, and $4.25 \%$. These outcomes show that the constituents have low the variation among specimens.

The extractive levels did not show any difference across treatments, but there were higher percentages in treatments $\mathrm{T} 1$ and $\mathrm{T} 2$. This can be explained by the fact that the wood was treated with tannin extract, which is produced by the species itself.

Lignin presented varied results; T1 did not differ from the lower and higher controls. However, when the increases are analyzed, T1 showed an increase by more than $4 \%$ over the higher control, showing a preservative effect in the samples that received $\mathrm{T} 1$. By comparison, the samples that received $\mathrm{T} 2$ and $\mathrm{T} 3$ had better results than the lower control. Thus, these treatments were efficient in preserving lignin as they did not differ from the higher control (control samples).

Regarding holocellulose levels, with the exception of the comparison between the higher control and T3, all contrasts were significant, indicating superiority of treatments $\mathrm{T} 1$ and $\mathrm{T} 2$ compared with the lower control. However, the treatments with the tannin extract underperformed T3, hence the chemical preservative had better performance than the natural product.

Nevertheless, when hemicellulose level is analyzed, it can be seen that the treatments were not different from the higher control; also, they reduced the loss of this component when compared to the lower control. When the average cellulose levels were analyzed, all treatments with the tannin extract decreased the decomposition of this component.

Table IV shows high correlation between weight loss and the levels of lignin, cellulose and hemicellulose. However, for the extractive levels, correlation was lower. This may occur because wood undergoes a wide range of changes during rotting, causing changes in the chemical composition of the cell wall during exposure to fungus attack (Schmidt 2006, Maresi et al. 2013, Bari et al. 2014).

The most common method of cell decomposition by white rot fungus is called simultaneous deterioration, whereby carbohydrates and lignin are attacked equally (Worrall et al. 1997, Arantes et al. 2011). Based on the data shown in the present study, the simultaneous decomposition of wood components was identified, and the greatest reductions occurred in lignin and cellulose levels.

The extractive levels did not show an expressive reduction after three months of experimentation, while the levels of lignin and holocellulose had 5 to $10 \%$ loss, respectively, when compared to the initial levels. The complexity of the cell wall and its chemical composition as well as the different enzymatic mechanisms of rotting fungus, are directly associated with wood rotting (Schmidt 2006). This is indicative of the importance of this kind of correlation in the fungal deterioration process (Bari et al. 2014).

TABLE IV

Pearson's correlation coefficients between weight loss and chemical properties of wood.

\begin{tabular}{cccccc}
\hline & Weight Loss & Extractives & Lignin & Cellulose & Hemicellulose \\
\hline Weight Loss & 1 & -0.65 & $-0.99 *$ & $-0.99 *$ & $-0.99 *$ \\
Extractives & & 1 & 0.69 & 0.59 & 0.66 \\
Lignin & & & 1 & $0.98^{*}$ & $0.99 *$ \\
Cellulose & & & 1 & $0.99^{*}$ \\
Hemicellulose & & & & 1 \\
\hline
\end{tabular}

*Significant at $5 \%$ of error probability. 


\section{CONCLUSIONS}

The natural resistance of the wood of Acacia mearnsii is classified as moderate; The treatments using tannin at $5 \%$ and $10 \%$ presents similar results to those of the CCB mixture, where the biological resistance of the wood was classified as very resistant; As for chemical analysis, decomposition did not have a significant influence on the level of extractives. Natural treatments were effective in preserving contents of lignin and holocellulose, which were affected in a similar manner as wood treated with chemical products.

In general, it can be stated that tannin has the potential to be considered as a natural wood preservative; there should be new evaluations considering other species and with other organisms, as well as evaluations of tannin fixation in the wood.

\section{REFERENCES}

ARANGO AR, GREEN F, HINTZ K, LEBOW PK AND MILLER RB. 2005. Natural Durability of Tropical and native woods against termite damage by Reticulutermers flavipes. International Biodeterior Biodegrad 57: 146-150.

ARANTES V, MILAGRES AMF, FILLEY TR AND BARRY G. 2011. Lignocellulosic polysaccharides and lignin degradation by wood decay fungi: the relevance of nonenzymatic Fenton-based reactions. J Ind Microbiol Biotechnol 38: 541-555.

ASHADUZZAMAN M, DAS AK, KAYES I AND SHAMS MI. 2011. Natural decay resistance of Acacia auriculiformis Cunn. ex. Benth and Dalbergia sissoo Roxb. Bangladesh J Sci Ind Res 46(2): 225-230.

ASTM D-2017 - AMERICAN SOCIETY FOR TESTING AND MATERIALS. 1994. Standard method for accelerated laboratory test of natural decay resistance for woods. Philadelphia.

BARI E, TAGHIYARI HR, MOHEBBY B, CLAUSEN CA, SCHMIDT O AND VASEGHI MJ. 2014. Mechanical properties and chemical composition of beech wood exposed for 30 and 120 days to white-rot fungi. Holzforschung 69(5): 587-593.

CHAN JM, DAY P, FEELY J, THOMPSON R, LITTLE KM AND NORRIS CH. 2015. Acacia mearnsii industry overview: current status, key research and development issues. South Forests 77(1): 19-30.

CHEN CM. 1991. Effects of extraction on reaction of bark extracts with formaldehyde. Holzforschung 45: 7-10.
FERAYDONI V AND HOSSEINIHASHEMI SK. 2012. Effect of walnut heartwood extractives, acid copper chromate, and boric acid on white-rot decay resistance of treated beech sapwood. BioResources 7(2): 2393-2402.

GERENGI H, TASCIOGLU C, AKCAY C AND KURTAY M. 2014. Impact of Copper Chrome Boron (CCB) Wood Preservative on the Corrosion of St37 Steel. Ind Eng Chem Res 53(49): 19192-19198.

GONZÁLEZ-LAREDO RF, ROSALES-CASTRO M, ROCHA-GUZMÁN NE, GALLEGOS-INFANTE JA, MORENO-JIMÉNEZ MR AND KARCHESY J. 2015. Wood preservation using natural products. Madera Bosques 21: 63-76.

GOSH SC, DYCKMANS J, MILITZ H AND MAI C. 2012. Effect of quat-and amino-silicones on fungal colonization and decay of wood. Holzforschung 66: 1009-1015.

ISLAM MM, SHAMS MI, ILIAS GNM AND HANNAN MO. 2009. Protective antifungal effect of neem (Azadirachta indica) extracts on mango (Mangifera indica) and rain tree (Albizia saman) wood. Int Biodeter Biodegr 63(2): 241243.

KARIMI A, TAGHIYARI HR, FATTAHI A, KARIMI S, EBRAHIMI G AND TARMIAN T. 2013. Effects of wollastonite nanofibers on biological durability of poplar wood (Populus nigra) against Trametes versicolor. BioResources 8(3): 4134-4141.

LAKS PE, MCKAIG PA AND HEMINGWAY RW. 1988. Flavonoid Biocides: Wood Preservatives Based on Condensed Tannins. Holzforschung 42(5): 299-306.

MARESI G, OLIVEIRA LONGA CM AND TURCHETTI T. 2013. Brown rot on nuts of Castanea sativa Mill: an emerging disease and its causal agent. IFOREST 6: 294301.

MOHAN D, SHI J, NICHOLAS DD, PITTMAN JR CU, STEELE PH AND COOPER JE. 2008. Fungicidal values of bio-oils and their lignin-rich fractions obtained from wood/bark fast pyrolysis. Chemosphere 71(3): 456-465.

MORRIS PI AND STIRLING R. 2012. Western red cedar extractives associated with durability in ground contact. Wood Sci Technol 46: 991-1002.

ROUX DG. 1992. Reflections on the chemistry and affinities of the major commercial condensed tannins in the context of their industrial use. In: Hemingway RW and Laks PE (Eds), Plant Polyphenols. Plenum Press, New York: USA, p. 7-39.

SCHMIDT O. 2006. Wood and Tree Fungi: Biology, Damage, Protection, and Use. Germany: Springer-Verlag.

STIRLING R. 2010. Residual Extractives in Western Red Cedar Shakes and Shingles after Long-Term Field Testing. For Prod J 60(4): 353-356.

TAPPI - TECHNICAL ASSOCIATION OF THE PULP AND PAPER INDUSTRY. 1996a. T 264 om-88: preparation of wood for chemical analysis. Atlanta. 
TAPPI - TECHNICAL ASSOCIATION OF THE PULP AND PAPER INDUSTRY. 1996b. T 204 om-88: solvent extractives of wood and pulp. Atlanta.

TAPPI - TECHNICAL ASSOCIATION OF THE PULP AND PAPER INDUSTRY. 1999. T 222 om-02: Acid - insoluble lignin in wood and pulp. Atlanta.

TAPPI - TECHNICAL ASSOCIATION OF THE PULP AND PAPER INDUSTRY. 2002a. T 257: sampling and preparing wood for analysis. Atlanta.

TAPPI - TECHNICAL ASSOCIATION OF THE PULP AND PAPER INDUSTRY. 2002b. T 19 om-54: holocellulose in wood. Atlanta.

TAPPI - TECHNICAL ASSOCIATION OF THE PULP AND PAPER INDUSTRY. 2009. T 203 cm-99: alpha-, beta- and gamma-cellulose in pulp. Atlanta.

TASCIOGLU C, YALCIN M, DE TROYATAND SIVRIKAYA H. 2012. Termiticidal properties of some wood and bark extracts used as wood preservatives. BioResources 7(3): 2960-2969.

TASCIOGLU C, YALCIN M, SEN S AND AKCAY C. 2013. Antifungal properties of some plant extracts used as wood preservatives. Int Biodeter Biodegr 85: 23-28.

TAYLOR AM, GARTNER BL, MORRELL JJ AND TSUNODA K. 2006. Effects of heartwood extractive fractions of Thuja plicata and Chamaecyparis nootkatensis on wood degradation by termites or fungi. J Wood Sci 52: 147-153.

TEMIZ A, TERZIEV N, EIKENES M AND HAFREN J. 2007. Effect of accelerated weathering on surface chemistry of modified wood. Appl Surf Sci 253: 5355-5362.
TONDI G, HU JB AND THEVENON MF. 2015. Advanced Tannin Based Wood Preservatives. For Prod J 65(3-4): S26-S32.

TONDIG, WIELAND S, LEMENAGERN, PETUTSCHNIGG A, PIZZI A AND THEVENON MF. 2012. Efficacy of tannin in fixing boron in wood. BioResources 7(1): 12381252.

VIDAL JM, EVANGELISTA WV, SILVA JDC AND JANKOWSKY IP. 2015. Preservação de madeiras no Brasil: Histórico, cenário atual e tendências. Cienc Florest 25: 257-271.

WALKER JCF. 2006. Basic wood chemistry and cell wall ultrastructure. In: Primary wood processing: principles and practice. Dordrecht: Springer, p. 23-67.

WINANDY JE. 1995. Effects of fire retardant treatments after 18 months of exposure at $150^{\circ} \mathrm{F}\left(66^{\circ} \mathrm{C}\right)$. Res. Note FPLRN-0264. Department of Agriculture, Forest Service, Forest Products Laboratory, $13 \mathrm{p}$.

WINANDY JE AND LEBOW PK. 1996. Kinetic model of the effects of fire retardants on properties of wood at elevated temperature. Wood Fiber Sci 28: 39-52.

WORRALL JW, ANAGNOST SE AND ZABEL RA. 1997. Comparison of wood decay among diverse lignicolous fungi. Mycologia 89: 199-219.

YAMAGUCHI H AND OKUDA KI. 1998. Chemically modified tannin and tannin-copper complexes as wood preservatives. Holzforsch 52: 596-602. 